\title{
Pemanfaatan Metode Diskusi Untuk Meningkatkan Keaktifan Siswa Dan Hasil Belajar Materi Proses Fotosintesis Siswa Kelas V Sd Inpres 68 Klasaman Kota Sorong
}

\author{
Sukatno \\ SD Inpres 68 Klasaman Kota Sorong \\ Email: sukatno794@gmail.com
}

\begin{abstract}
This study aimed to determine the improvement of students' activeness and learning result in the material of photosynthesis process for $V$ grade students of SD Inpres 68 Klasaman Sorong City through discussion method. This research was classroom action research which was conducted in 2 cycles. Every cycle consisted of 4 steps those were planning, action, observation and reflection. The data collection techniques used were observation, documentation and test. The results showed that: (a) the participation of students showed improvement in each cycle. In cycle I, the average percentage of student activity was 30, 76\% and the average percentage in cycle II of student activity was $84,61 \%,(b)$ The results of the students' learning experience were increased significantly. In cycle I class average value was 66, 92, while in the cycle II, the average value was 85 . This showed that the value was above the KKM.

Keywords: discussion method, Photosynthesis, students' activeness, learning result, SD Inpres 68 Klasaman Sorong City
\end{abstract}

\begin{abstract}
Abstrak: Penelitian ini bertujuan untuk menentukan peningkatan keaktifan dan hasil belajar siswa pada materi fotosintesis melalui pemanfaatan metode diskusi pada siswa kelas V SD Inpres 68 Klasaman. Penelitian ini merupakan penelitian tindakan kelas yang dilakukan dalam 2 siklus. Masingmasing siklus terdiri dari 4 tahapan, yakni perencanaan, tindakan, pengamatan dan refleksi. Teknik pengumpulan data yang digunakan dalam penelitian ini adalah observasi, dokumentasi dan tes. Berdasarkan hasil penelitian ditunjukkan bahwa: (a) partisipasi siswa meningkat pada setiap siklus. Pada siklus I, nilai rata-rata aktivitas siswa adalah $30,76 \%$ dan meningkat menjadi $84,61 \%$ pada siklus II, (b) hasil belajar siswa meningkat secara signifikan. Pada siklus I, nilai rata-rata kelas adalah 66,92 dan pada siklus II nilai rata-rata kelas menjadi 85 . Hal ini menunjukkan bahwa nilai tersebut berada di atas nilai KKM.
\end{abstract}

Kata Kunci: metode diskusi, fotosintesis, keaktifan siswa, hasil belajar, SD Inpres 68 klasaman Kota Sorong

\section{Pendahuluan}

SD Inpres 68 Klasaman Kota Sorong merupakan salah satu sekolah dasar yang memiliki kreteria ketuntasan minimal dalam mata pelajaran IPA adalah 70. Sehingga banyak warga di sekitar Kota sorong khusunya wilayah Kelurahan klawuyuk memilih SD Inpres 68 Klasaman Kota Sorong untuk menitipkan anak-anaknya di sekolah tersebut.

Kondisi di atas tidak sesuai dengan harapan peneliti. Saat peneliti mengajar di kelas V dijumpai $75 \%$ siswa tidak memahami materi pelajaran IPA Khususnya Fotosintesis. Siswa saat kegiatan pembelajaran jika ditanya guru tidak mampu menjawab. Apalagi jika diminta bertanya. Separuh siswa tidak berani mengemukakan pendapat.

Peneliti merasa bahwa kemampuan menguasai materi kemampuan mengidentifikasi proses fotosintesis perlu dipahami siswa. Hal ini di karenakan nilai rata-rata kelas belum mencapai KKM yang diharapkan. Selain itu saat ditanya guru siswa tidak mampu menjawab. Saat kegiatan belajar mengajar suasana kelas sangat monoton sehingga perlu dicari strategi pembelajaran yang merangsang siswa untuk aktif, kreatif, dan menyenangkan.

Berdasarkan uraian di atas maka penulis tertarik untuk melakukan penelitian dengan mengambil judul "Pemanfaatan metode diskusiuntuk Meningkatkan hasil belajar siswa pada materi fotosisntesis di kelas V di SD Inpres 68 Klasaman Kota Sorong". 


\section{Metode Penelitian}

\subsection{Desain Penelitian}

Penelitian ini merupakan penelitian tindakan kelas (classroom action research), yaitu sebuah penelitian tindakan yang dilakukan oleh guru di dalam kelas dengan tujuan memperbaiki mutupembelajaran di dalam kelas (Wardani dkk, 2004; Arikunto, S., 2006; Suhardjono, 2006). Pembelajaran yang diharapkan dapat dihasilkan dari PTK adalah peningkatan atau perbaikan mutu proses dan hasil pembelajaran, antara lain meliputi, Peningkatan atau perbaikan terhadap kinerja belajar siswa di sekolah, 2) Peningkatan atau perbaikan terhadap mutu proses pembelajaran di kelas, 3) Peningkatan atau perbaikan terhadap kualitas penggunaan media, alat bantu belajar dan sumber belajar lainnya, 4) Peningkatan atau perbaikan terhadap kualitas prosedur alat evaluasi yang digunakan untuk mengukur proses dan hasil belajar siswa, 5) Peningkatan atau perbaikan terhadap masalah pendidikan anak di sekolah, 6) Peningkatan atau perbaikan terhadap kualitas penerapan kurikulum dan pengembangan kompetensi siswa di sekolah.

Sebelum mengadakan penelitian, peneliti terlebih dahulu mengawali dengan pra-penelitian.Kegiatan ini dilakukan terhadap mata pembelajaran (mapel) sebelum menggunakan diskusi.Kegiatan yang dilakukan yaitu mengadakan observasi terhadap situasi awal di dalam kelas yang mencakup observasi kegiatan guru, observasi kelas dan observasi terhadap siswa.Setelah mengadakan kegiatan prapenelitian, peneliti mengadakan penelitian di dalam kelas dengan menggunakan diskusi.

Penelitian ini dilakukan dalam bentuk siklus, masing-masing siklus terdiri dari perencanaan, tindakan, pengamatan dan refleksi. Penelitian ini didesain sebagai Penelitian Tindakan Kelas (PTK) yang akan dilakukan dengan beberapa siklus.

\subsection{Subjek Penelitian}

Subjek dalam penelitian ini adalah siswa kelas V SD Inpres 68 Klasaman Kota Sorong, yang terdiri dari 17 laki-laki dan 9 perempuan.

\subsection{Teknik Pengumpulan Data}

Data dalam penelitian ini dikumpulkan dengan beberapa teknik, yaitu : observasi, wawancara, dokumentasi dan tes.

\subsection{Teknik Analisis Data}

Dalam penelitian ini, peneliti menggunakan beberapa teknis analisis data diantaranya adalah sebagai berikut :

a. Untuk validitasi instrumen penelitian menggunakan Pearson Product Moment (PPM) dan Reabelitas menggunakan Spearmean Brown

$$
\begin{gathered}
r_{\text {hitung }}=\frac{n(\Sigma X Y)-(\Sigma X) \cdot(\Sigma Y)}{\sqrt{\left\{n \cdot \Sigma X^{2}-(\Sigma X)^{2}\right\} \cdot\left\{n \cdot \Sigma Y^{2}-\left(\Sigma Y Y^{2}\right\}\right.}} \\
r_{11}=\frac{2 \cdot r b}{1+r_{b}}
\end{gathered}
$$

Uji Validaitasi dan reliabilitasi instrumen peneliti lakukan di sekolah lain yang berada di wilayah aimas, yang peneliti anggap sama. Korelasi PPM dilambangkan dengan (r) dengan ketentuan nilai tidal lebih dari harga $(-1 \leq \mathrm{r} \leq+1)$. Apabila nilai $\mathrm{r}-1$, artinya korelasinya negatif sempurna, $\mathrm{r}=0$ tidak ada korelasi, dan $r=+1$ berati korelasinya positif sempurna/sangat kuat. Sedangkan arti harga $r$ diasumsikan dengan harga tabel berikut:

Tabel 1. Interpretasi Koefesien Korelasi Nilai $r$

\begin{tabular}{cc}
\hline Interval Koefesien & Tingkat Hubungan \\
\hline $0,80-1,000$ & Sangat kuat \\
$0,60-0,799$ & Kuat \\
$0,40-0,599$ & Cukup kuat
\end{tabular}


Pada pengujuian reliabelitas ini menggunakan Rumus Spearman Brown

Keterangan :

$$
r_{11}=\frac{2 \cdot r_{b}}{1+r_{b}}
$$

r11 = Koefesien Reliabelitas internal seluruh item

$\mathrm{rb}=$ Korelasi PPM

Sesuai dengan hipotesis penelitian ini, yakni diduga ada peningkatan keaktifan dan hasil belajar siswa, maka untuk menguji hipotesissnya dilakukan uji sebagai berikut:

\section{a. Partisipasi aktif siswa}

Untuk mengetahui apakah metode diskusidapat membuat siswa lebih aktif dalam mengikuti mata pelajaran (mapel), data yang digunakan terdapat pada lembar observasi yang kemudian dianalisis secara deskriptif. Penilaian dapat dilihat dari hasil skor pada lembar observasi yang digunakan. Data observasi yang telah diperoleh, dihitung, kemudian dipersentasekan. Sehingga dapat diketahui seberapa besar peningkatan partisipasi siswa dalam pembelajaran. Kriteria menghitung persentase partisipasi siswa berdasarkan lembar observasi adalah sebagai berikut :

Tabel 2. Kriteria Aktivitas Individu

\begin{tabular}{cc}
\hline Persentase & kriteria aktivitas siswa \\
\hline $81 \%-100 \%$ & Sangat Tinggi \\
$61 \%-80 \%$ & Tinggi \\
$41 \%-60 \%$ & Sedang \\
$21 \%-40 \%$ & Rendah \\
$0 \%-20 \%$ & Sangat Rendah \\
\hline
\end{tabular}

(Riduwan, 2009: 15)

Cara menghitung persentase aktivitas siswa berdasarkan lembar observasi untuk tiap pertemuan adalah sebagai berikut :

$$
\begin{aligned}
& \text { Skor Perolehan } \\
& \text { Persentase }=\frac{(\text { Juml. Siswa Yang Berpartisipasi) }}{\text { Skor Maksimal }} \times 100 \% \\
& \text { (Juml.Siswa Keseluruhan) }
\end{aligned}
$$

(Martinus, 2013: 49)

Dalam penelitian ini indikator yang dicapai bisa dilihat dari pencapaian poin-poin yang tertera dalam partisipasi belajar siswa. Adapun poin-poin yang diamati untuk mengukur peningkatan partisipasi antara lain:

1. mendengar penjelasan,

2. mencatat penjelasan,

3. memperhatikan pembelajaran,

4. bertanya,

5. menjawab pertanyaan,

6. mengeluarkan pendapat,

7. menghargai pendapat teman,

8. mampu menjelaskan kembali.

b. Hasil Belajar Siswa

Untuk mengetahui peningkatan prestasi belajar siswa, peneliti menggunakan Kriteria Ketuntasan Minimal (KKM) pada mata pelajaran (mapel), yaitu 70. Bila siswa telah mencapai nilai sama atau lebih besar dari 70 dengan prosedur rentang nilai 00-100, maka dapat dikatakan memenuhi KKM. Tetapi apabila siswa mendapatkan nilai kurang dari 70 dikatakan masih di bawah KKM. 


\section{Hasil dan Pembahasan}

\subsection{Hasil Penelitian}

\subsubsection{Uji Validatas dan Reliabelitas Instrumen}

Tujuan peneliti melakukan hal ini adalah untuk memperoleh data kevalid-an dan ke-reliabel-an data tentang pemanfaatn metode diskusi untuk meingkatkan prestasi siswa. Instrumen berjumlah 15 soal pilihan gandayang diujikan di SD Inpres 68 Klasaman Kota Sorong. Setelah dilakukan uji validitas menggunakan Pearson Product Moment (PPM) melalui SPSS.16.00, maka hasil validitasinya adalah sebagai berikut:

Tabel 3. Hasil Validitas Instrumen Penelitian

\begin{tabular}{cccc}
\hline No. Urut & R Hitung & $\begin{array}{c}\text { Syarat Yang } \\
\text { ditentukan }\end{array}$ & $\begin{array}{c}\text { Tingkat } \\
\text { Validitas }\end{array}$ \\
\hline 1 & 0,36 & $>0,3$ & Valid \\
2 & 0,363 & $>0,3$ & Valid \\
3 & 0,566 & $>0,3$ & Valid \\
4 & 0,36 & $>0,3$ & Valid \\
5 & 0,556 & $>0,3$ & Valid \\
6 & 0,341 & $>0,3$ & Valid \\
7 & 0,556 & $>0,3$ & Valid \\
8 & 0,341 & $>0,3$ & Valid \\
9 & 0,526 & $>0,3$ & Valid \\
10 & 0,332 & $>0,3$ & Valid \\
11 & 0,4 & $>0,3$ & Valid \\
12 & 0,499 & $>0,3$ & Valid \\
13 & 0,04 & $>0,3$ & Valid \\
14 & 0,417 & $>0,3$ & Valid \\
15 & 0,526 & $>0,3$ & Valid \\
\hline
\end{tabular}

Tabel 4. Tabel reliabelitas pada instrumen

\section{Reliability Statistics}

\begin{tabular}{cc}
\hline Cronbach's Alpha & N of Items \\
\hline 0,547 & 26 \\
\hline
\end{tabular}

Berdasarkan Tabel 4, Interpretasi Koefesien Korelasi Nilai r, maka kereliabelan instrumen tersebut cukup kuat, dimana nilai 0,547 berada pada rentan 0,40-0,599 yang artinya tingkat kerilibelannya cukup kuat.

\subsubsection{Hasil Tindakan}

Selama kegiatan belajar mengajar berlangsung observer melakukan pengamatan secara langsung mengenai partisipasi yang ditunjukkan oleh siswa dalam mata pelajaran (mapel). Dalam penelitian ini, unsur-unsur yang termasuk dalam partisipasi siswa atau keaktifan siswa meliputi mendengarkan penjelasan guru, mencatat penjelasan guru, memperhatikan pembelajaran, bertanya, menjawab pertanyaan, mengeluarkan pendapat, menghargai pendapat teman, refleksi/menjelaskan kembali. Maka dari indikator-indikator tersebut, hasil dari lembar pengamatannya sebagai berikut:

Tabel 5. Hasil Observasi Partisipasi Aktif Siswa pada Siklus I

$\begin{array}{lll}\text { ASPEK YANG DIAMATI } & \text { JUML. SISWA } & \text { PARTISIPASI AKTIF }\end{array}$




\begin{tabular}{lccc}
\hline & & JUML SISWA & \% \\
\hline Mendengarkan Penjelasan & 26 & 20 & 76,92308 \\
Mencatat Penjelasan & 26 & 15 & 57,69231 \\
Memperhatikan Pembelajaran & 26 & 13 & 50 \\
Bertanya & 26 & 5 & 19,23077 \\
Menjawab Pertanyaan & 26 & 3 & 11,53846 \\
Mengeluarkan Pendapat & 26 & 2 & 7,692308 \\
Menghargai Pendapat Teman & 26 & 5 & 19,23077 \\
Mampu Menjelaskan Kembali & 26 & 1 & 3,846154 \\
& Jumlah & & 246,1538 \\
& Rata-Rata & & 30,76923
\end{tabular}

Dari tabel dapat diketahui bahwa siswa yang mendengarkan penjelasan sebanyak $76,92 \%$, mencatat penjelasan 57,69 \%, memperhatikan pembelajaran $50 \%$, bertanya $19,23 \%$, menjawab pertanyaan $11,53 \%$, mengeluarkan pendapat 7,69 \%, menghargai pendapat teman $19,23 \%$, mampu menjelaskan kembali 3,84\%.

\subsubsection{Hasil Tes}

Berdasarkan rata-rata siswa pada post test I dapat diketahui sebesar 66,92308 Hal ini menunjukkan bahwa terjadi peningkatan hasil belajar siswa setelah menggunakan metode diskusipada mata pelajaran (mapel). Namun berdasarkan nilai siswa pada siklus 1 di atas, kriteria keberhasilan belum tercapai, karena masih terdapat 20 siswa belum mencapai KKM, sehingga perlu dilanjutkan dengan siklus berikutnya yaitu siklus II.

Dalam pembelajaran pada siklus I ini, tahap refleksi dilakukan oleh peneliti dan guru kolaborator untuk mengevaluasi hasil observasi partisipasi aktif siswa dan hasil dari pelaksanaan post test sebagai umpan balik setelah pembelajaran. Penggunaan metode diskusi meskipun belum maksimal, sebenarnya sudah menunjukkan partisipasi aktif siswa. Masih banyak siswa yang cenderung enggan untuk mengemukakan pendapat dan hal tersebut dikarenakan siswa belum terbiasa di dalam pembelajaran menggunakan diskusi, sehingga masih banyak siswa yang pasif dalam mengikuti pembelajaran. Pada pelaksanaan pembelajaran menggunakan metode diskusiuntuk meningkatkan partisipasi aktif siswa pada siklus I belum sepenuhnya terlaksana dengan baik. Hal ini terjadi, mungkin dikarenakan siswa masih canggung dengan pembelajaran menggunakan diskusi. Prestasi belajar pada siklus I juga belum menunjukkan hasil yang maksimal, meskipun telah banyak siswa yang memenuhi kriteria ketuntasan minimal tetapi masih ada juga siswa yang belum memenuhi.

Berdasarkan hasil refleksi tersebut, maka perlu adanya tindakan lanjutan untuk memperbaiki atau menyempurnakan pembelajaran dengan menggunakan diskusi. Dikarenakan belum tercapainya target tindakan yang diinginkan pada pelaksanaan tindakan pada siklus I, maka peneliti dan guru sepakat untuk melanjutkan tindakan pada siklus II.

\section{1) Pengamatan terhadap partisipasi aktif siswa (observasi)}

Selama kegiatan pembelajaran berlangsung observer melakukan pengamatan secara langsung mengenai partisipasi yang ditunjukkan oleh siswa dalam mata pelajaran (mapel). Pada siklus II ini tingkat partisipasi aktif siswa sudah mulai menunjukkan adanya peningkatan yang relatif stabil dan hampir semua siswa sudah memperhatikan, berpartisipasi dan mengikuti proses pembelajaran. Semua ini dapat dilihat dengan adanya peningkatan dari hampir semua aspek yang diamati. Hasil dari pengamatan siswa pada siklus II, dapat dilihat pada tabel berikut ini:

Tabel 6.Hasil Observasi Partisipasi Aktif Siswa pada Siklus II

ASPEK YANG DIAMATI TOT PARTISIPASI AKTIF




\begin{tabular}{lccc} 
& SISWA & JUML SISWA & \% \\
\hline Mendengarkan Penjelasan & 26 & 26 & 100 \\
\hline Mencatat Penjelasan & 26 & 26 & 100 \\
\hline Memperhatikan Pembelajaran & 26 & 26 & 100 \\
\hline Bertanya & 26 & 17 & 65,38 \\
\hline Menjawab Pertanyaan & 26 & 20 & 76,92 \\
\hline Mengeluarkan Pendapat & 26 & 10 & 38,46 \\
\hline Menghargai Pendapat Teman & 26 & 26 & 100 \\
\hline Mampu Menjelaskan Kembali & 26 & 25 & 96,15 \\
\hline \multicolumn{2}{c}{ Jumlah } \\
\hline
\end{tabular}

Dari tabel dapat diketahui bahwa siswa yang mendengarkan penjelasan sebanyak $100 \%$, mencatat penjelasan $100 \%$, memperhatikan pembelajaran $100 \%$, bertanya $65,38 \%$, menjawab pertanyaan $76,92 \%$, mengeluarkan pendapat $38,46 \%$, menghargai pendapat teman $100 \%$, mampu menjelaskan kembali $96,15 \%$.

Tabel 7. Hasil Perhitungan Tes pada Siklus I dan Siklus II

\begin{tabular}{|c|c|c|c|}
\hline No & Nama Siswa & Tes Siklus I & Tes Siklus II \\
\hline 1 & Ade bilal akbar & 65 & 80 \\
\hline 2 & Alexandro f. Kaikatui & 60 & 85 \\
\hline 3 & Alfred pandi pairunan & 66 & 80 \\
\hline 4 & Sarah & 67 & 86 \\
\hline 5 & Suci Apsah Azis & 68 & 88 \\
\hline 6 & Chrisjanuari caesar bessoran & 65 & 90 \\
\hline 7 & Fiani fidesia turot & 70 & 80 \\
\hline 8 & Firdah anisah azzahrah & 75 & 80 \\
\hline 9 & Firman syah & 65 & 88 \\
\hline 10 & Friel frits lapon & 65 & 89 \\
\hline 11 & Frieland daniel leihitu & 65 & 90 \\
\hline 12 & Gervasia cindya jebaun & 60 & 80 \\
\hline 13 & Jesica anro latuasan & 66 & 85 \\
\hline 14 & Karlina lestari & 67 & 80 \\
\hline 15 & Katerina ovaliana welerubun & 68 & 86 \\
\hline 16 & Maman triarso & 65 & 88 \\
\hline 17 & Marwan lestaluhu & 70 & 90 \\
\hline 18 & Miftakhul faidon & 75 & 80 \\
\hline 19 & Muh.syahrul bachtiar & 65 & 80 \\
\hline 20 & Muhamad faathir ibnu do"ny" & 65 & 88 \\
\hline 21 & Muhammad khairin & 68 & 90 \\
\hline 22 & Nova ayu nurhidayah & 65 & 80 \\
\hline 23 & Rahmat fajar & 70 & 80 \\
\hline 24 & Ranny gracia trifena jitmau & 76 & 88 \\
\hline 25 & Ricard saputra toisuta & 65 & 89 \\
\hline \multirow[t]{3}{*}{26} & Rizky inka nur bintari & 65 & 90 \\
\hline & $\sum$ Nilai & 1740 & 2210 \\
\hline & Rata-rata & 66,92308 & 85 \\
\hline
\end{tabular}


Setelah dilakukan penelitian yang dimulai dari tahapan siklus I, sampai pada tahapan siklus II dapat dilihat adanya peningkatan partisipasi aktif danprestasi belajar siswa dengan menggunakan diskusi. Berdasarkan pemaparan prestasi belajar di atas dapat diberikan penjelasan bahwa telah terjadi peningkatan prestasi belajar siswa dari siklus I mencapai rata-rata $66,92 \%$ naik menjadi rata-rata $85 \%$ pada tahap siklus II. Dari rata-rata tersebut dapat diketahui peningkatan rata-rata 75,96\% dari siklus I ke siklus II. Dapat disimpulkan bahwa dengan penggunaan metode diskusipada mata pelajaran (mapel) dapat meningkatkan prestasi belajar siswa.

Berdasarkan rata-rata hasil belajar antara tes pada siklus I dan siklus II yang diketahui bahwa pada tes II (85) mempunyai rata-rata lebih tinggi dibandingkan dengan rata-rata pada tes yang dilakukan di siklus I $(66,92)$. Hal ini menunjukkan adanya terjadi peningkatan pada hasil belajar pada siklus II dalam mata pelajaran (mapel). Berdasarkan rata-rata pada siklus II di atas, kriteria keberhasilan sudah tercapai karena lebih dari $100 \%$ siswa telah mencapai KKM, hal ini menunjukkan adanya pencapaian tingkat keberhasilan sesuai dengan kriteria keberhasilan yang telah ditetapkan.

\subsection{Pembahasan}

\subsubsection{Pelaksanaan Penelitian Tindakan Kelas Menggunakan Diskusi}

Pelaksanaan metode diskusi untuk meningkatkan partisipasi aktif dan prestasi belajar siswa dilakukan dalam dua siklus.Penerapan metode diskusipada siklus I pelaksanaannya belum tercipta peningkatan partisipasi aktif dan prestasi belajar siswa secara maksimal, maka peneliti sepakat untuk melanjutkan pada siklus berikutnya yaitu siklus II. Siklus demi siklus terbentuk untuk memberikan perbaikan dan perbandingan di dalam pembelajaran agar partisipasi aktif dan prestasi belajar lebih meningkat sesuai dengan apa yang diharapkan peneliti.

Dari pernyataan tersebut dapat disimpulkan bahwa mata pelajaran (mapel) dengan menggunakan metode diskusiini dapat memberi kemudahan bagi siswa dalam memahami materi yang diberikan guru. Dalam pembelajaran siklus I masih ada siswa yang kurang dapat memahami materi pelajaran, permasalahan yang diberikan oleh guru serta belum semua siswa menunjukkan partisipasi aktif selama proses pembelajaran dengan menggunakan metode diskusiini. Akan tetapi setelah siklus II para siswa berangsur-angsur dapat memahami materi, serta hampir semua siswa berpartisipasi aktif selama proses pembelajaran dengan menggunakan diskusi. Untuk menilai kriteria keberhasilan prestasi belajar siswa, peneliti menggunakan kriteria ketuntasan minimal (KKM) yang ditetapkan SD Inpres 68 Klasaman Kota Sorong Dalam mengadakan penilaian peneliti mengukur keberhasilan prestasi siswa menggunakan soal setelah tindakan dilakukan.

\subsubsection{Partisipasi Aktif Siswa}

Hasil penelitian tindakan siklus I dan II dengan penggunaan metode diskusimenunjukkan adanya peningkatan terhadap aktivitas belajar siswa.Peningkatan terjadi pada observasi siklus II di mana dalam observasi ini yang diamati adalah partisipasi aktif siswa. Dari hasil observasi diperoleh data aktivitas siswa sebagai berikut:

Berdasarka hasil observasi yang dapat dilihat dari tabel di atas dapat dilihat adanya peningkatan frekuensi dari siklus I sampai ke siklus II.Setiap indikator masing-masing siklus juga mengalami peningkatan. Pada siklus I dan siklus II peningkatan partisipasi siswa yang paling tinggi adalah mendengarkan penjelasan, mencatat penjelasan, memperhatikan pembelajaran,dan menghargai pendapat teman, karena terjadi peningkatan menjadi $100 \%$ dan peningkatan partisipasi aktif siswa yang paling rendah adalah indikator mengeluarkan pendapat, karena hanya terjadi peningkatan sebesar 38, $46 \%$.Jadi dapat disimpulkan bahwa dengan penggunaan metode diskusidalam mata pelajaran (mapel) dapat meningkatkan partisipasi aktif siswa dalam proses pembelajaran. Untuk membuktikannya dapat dilihat dalam diagram berikut:

Peningkatan Partisipasi Aktif Siklus I dan Siklus II

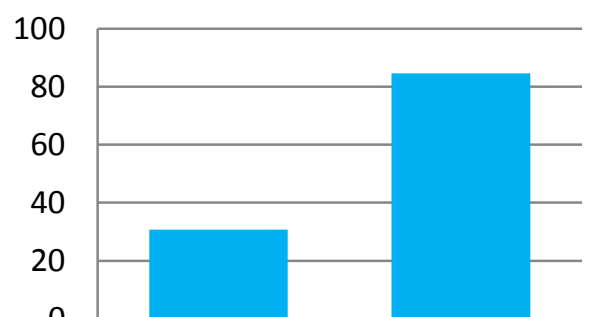


Gambar 1.Diagram Peningkatan Aktif Siklus I dan Siklus II

\subsubsection{Prestasi Belajar Siswa}

Penilaian yang digunakan pada setiap siklus adalah dengan menggunakan tes dan dilaksanakan pada setiap akhir siklus dengan soal-soal yang sesuai dengan materi yang diberikan kepada siswa.Hal ini dilakukan untuk mengukur sejauh mana siswa dapat menguasai materi yang telah disampaikan menggunakan diskusi.Hasil penelitian tindakan siklus I dan II dengan penggunaan metode diskusimenunjukkan adanya peningkatan terhadap prestasi belajar siswa.

Dari pernyataan tersebut, dapat disimpulkan bahwa dengan menggunakan metode diskusidapat menaikkan ingatan yang berarti dapat meningkatkan pestasi beajar siswa. Peningkatan prestasi belajar siswa dapat dilihat pada tabel berikut:

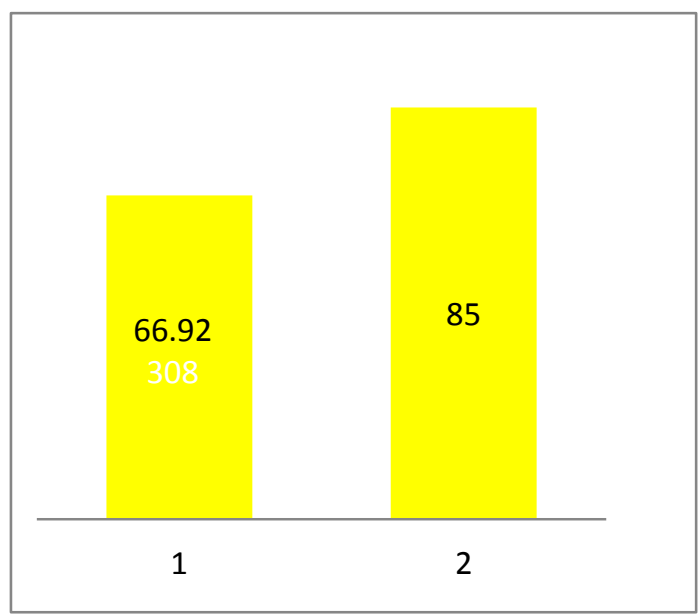

Gambar 2. Diagram Nilai Rata-Rata Kelas

Pada diagram di atas menunjukkan bahwa terdapat peningkatan rata-rata nilai hasil belajar dari siklus I sebesar 66, 92 sedangkan pada siklus II meningkat menjadi sebesar 85.Dalam ketuntasan individu setiap siklus, berdasarkan KKM sekolah, maka pada siklus 1 yang memiliki nilai diatas atau sama dengan KKM sebanyak 6 orang sedangkan untuk siklus 2 yang memiliki nilai di atas KKM sebanyak 26 siswa. Untuk lebih jelasnya dapat dilihat dalam diagram berikut: 


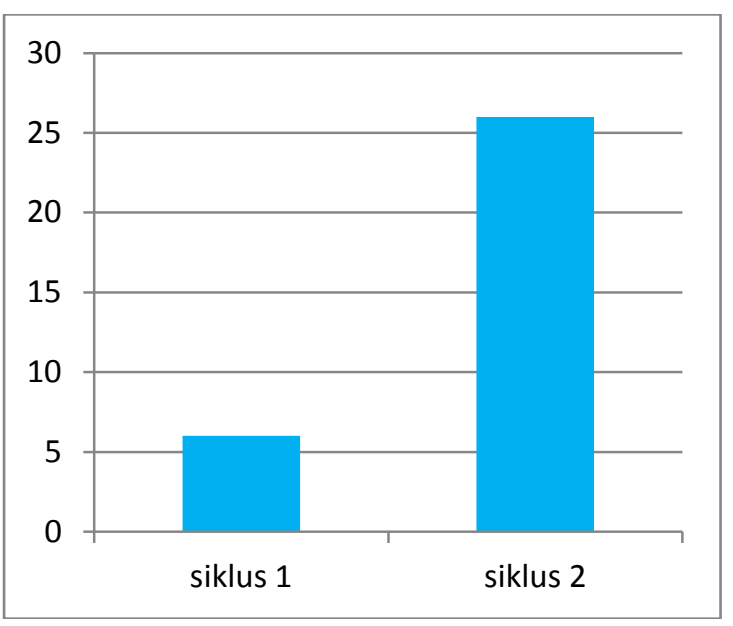

Gambar 3.Diagram Jumlah Tuntas Individu

Pada diagram di atas menunjukkan bahwa terdapat peningkatan jumlah tuntas individu atau siswa yang mencapai Kriteria Ketuntasan Minimal (KKM) dari siklus I sebesar 6 siswa sedangkan pada siklus II meningkat menjadi sebesar 26 siswa. Persentase ketuntasan pada setiap siklus dapat dilihat dalam diagram berikut:

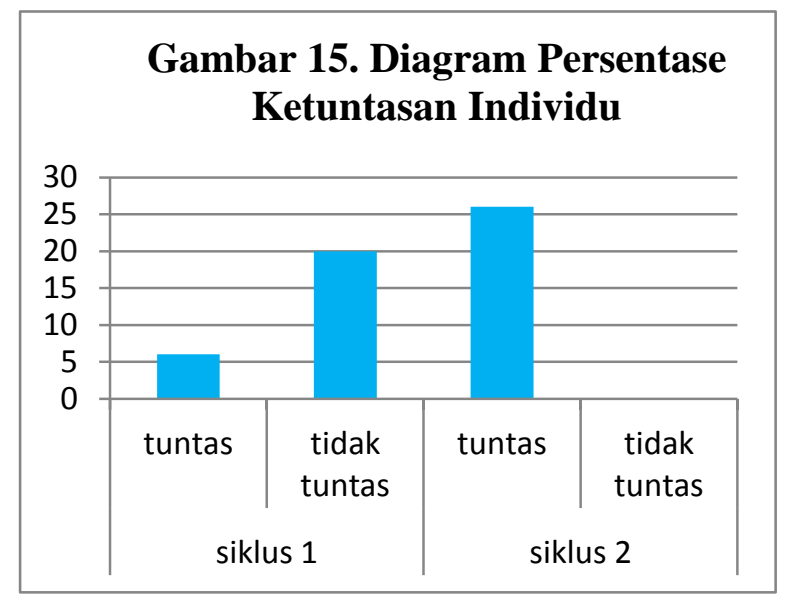

Gambar 4. Diagram Persentase Ketuntasan Individu

Pada gambar diagram diatas menunjukan bahwa terdapat peningkatan oersentase ketuntasan individu. Siklus I terdapat $23,07 \%$ siswa telah mencapai ketuntasan atau mencapai Kriteria Ketuntasan Minimal (KKM). Sedangkan Pada Siklus II terdapat $100 \%$ telah mencapai KKM.

\section{Simpulan dan Saran}

\subsection{Simpulan}

Berdasarkan hasil analisis data dan pembahasan yang telah peneliti lakukan, aktivitas belajar siswa kelas V di SD Inpres 68 Klasaman Kota Sorong untuk mata pelajaran (mapel), dapat ditarik kesimpulan sebagai berikut:

1. Penerapan pembelajaran dengan menggunakan metode diskusidapat meningkatkan kemampuan mengidentifikasi proses fotosintesis pada mata pelajaran (mapel) siswa kelas V IPA 5dilihat dari adanya peningkatan persentase,

2. Peningkatannya dapat dilihat dari hasil observasi pada siklus I dan siklus II. Pada Aspek mendengarkan penjelasan siklus I sebesar 76,92\% dan siklus II sebesar $100 \%$. Aspek mencatat 
penjelasan siklus I sebesar 57, $69 \%$ dan siklus II sebesar $100 \%$.Aspek memperhatikan pembelajaran siklus I sebesar $50 \%$ dan siklus II sebesar $100 \%$.Aspek bertanya siklus I sebesar $19,23 \%$ dan pada siklus II sebesar 65,38 \%.Aspek menjawab pertanyaan siklus I sebesar 11, 53 $\%$ dan siklus II sebesar 76, $93 \%$.Aspek mengeluarkan pendapat siklus I sebesar 7, $69 \%$ dan pada siklus II sebesar 38, $46 \%$.Aspek menghargai pendapat teman siklus I sebesar 19, $23 \%$ dan pada siklus II sebesar $100 \%$.Aspek mampu menjelaskan kembali siklus I sebesar 3, $84 \%$ dan pada siklus II sebesar $96,15 \%$. Hal ini menunjukkan

3. bahwa terjadi peningkatan terhadap partisipasi aktif siswa pada Standar Kompetensi kemampuan mengidentifikasi proses fotosintesis.

4. Metode diskusijuga dapat meningkatkan hasil belajar pada mata pelajaran (mapel) di kelas. Peningkatan hasil belajar ini dapat dilihat dari adanya perubahan nilai rata-rata yang diperoleh siswa pada setiap akhir siklus. Nilai rata-rata yang diperoleh siswa pada siklus I sebesar 66, 92 dan siklus II sebesar 85 . Hal tersebut membuktikan bahwa dengan menggunakan metode diskusidapat meningkatkan prestasi belajar siswa.

\subsection{Saran}

Berdasarkan hasil penelitian dan pembahasan maupun kesimpulan di atas, dapat diajukan beberapa saran:

1. Guru perlu mengupayakan partisipasi belajar siswa dengan cara melanjutkan pembuatan metode diskusipada mata pelajaran (mapel) untuk pertemuan-pertemuan selanjutnya agar siswa tertarik dalam memahami materi yang diberikan dalam proses pembelajaran sehingga partisipasi siswa dapat bertahan bahkan meningkat.

2. Guru perlu mengupayakan prestasi belajar siswa dengan cara melanjutkan pembuatan metode diskusipada mata pelajaran (mapel) untuk pertemuan-pertemuan selanjutnya agar siswa tertarik dalam memahami materi yang diberikan dalam proses pembelajaran sehingga prestasi siswa dapat bertahan bahkan meningkat.

\section{Daftar Pustaka}

Arikunto, Suharsimi. 2009. Dasar-dasar Evaluasi Pendidikan (Edisi Revisi, cetakan 7). Jakarta: Bumi Aksara

Arikunto, Suharsimi dkk. 2013. Penelitian Tindakan Kelas.Jakarta : Bumi Aksara.

Arikunto, Suharsimi. 2005. Prosedur Penelitian Suatu Pendekatan Praktek. Jakarta.Rineka Cipta.

Daradjat, Zakiah. 2000. Metodik Khusus Pengajaran Agama Islam. Jakarta. Bina Akasara

Engkoswara. 1984. Dasar-Dasar Metodologi Pengajaran. Jakarta: Bina Aksara

Halimatus, Sa'diyah. 2010. Efektifitas Metode Diskusi Dalam Pembelajaran Pendidikan Agama Islam

(Studi Kasus Di Smp Yapia Ciputat). Jakarta: UIN SHJ Press.

Mulyasa. 2004. Menjadi Guru professional. Bandung: PT Remaja Rosdakarya.

Ramayulis. 2001. Metodologi Pengajaran Agama Islam. Bandung: Pustaka Book

Riduwan. 2009. Skala Pengukuran Variabel-Variabel Penelitian. Bandung: Alfabeta.

Slameto. 2010. Belajar dan Faktor-Faktor yang Mempengaruhi. Jakarta: Rineka Cipta.

Sriyati, Siti. 2010. Penelitian Tindakan Kelas (PTK). Bandung: Pustaka Book.

Sudjana, Nana. 2006. Penilaian Hasil Proses Belajar Mengajar. Bandung: PT Remaja Rosdakarya.

Sugihartono. 2007. Psikologi Pendidikan. Yogyakarta: UNY Press.

Suryabrata, Sumadi. 2006. Psikologi Pendidikan. Jakarta: PT Raja Grafindo Persada.

Suryobroto. 1997. Proses Belajar Mengajar di Sekolah. Jakarta: PT Rineka Cipta.

Susilo. 2007. Panduan Penelitian Tindakan Kelas. Yogyakarta: Pustaka Book Publlisher.

Wiriaatmadja, Rochiati. 2009. Metode Penelitian Tindakan Kelas. Bandung: PT Remaja Rosdakarya. 